\title{
To What Extent Can the Professional Characteristics of NCATE Standards be Embedded in the Islamic Teacher Preparation Program?
}

\author{
Wajeha T. Al-Ani ${ }^{1^{*}}$ and Maimuna D. Al-Zadgali ${ }^{2}$ \\ ${ }^{1}$ Department of Educational Foundations and Administration, College of Education, Sultan Qaboos \\ University, Oman. \\ ${ }^{2}$ Department of Curriculum and Instruction, College of Education, Sultan Qaboos University, Oman.
}

\section{Authors' contributions}

This work was carried out in collaboration between both authors. Author WTAA designed the study, performed the statistical analysis, wrote the protocol and wrote the first draft of the manuscript. Author MDAZ managed the literature searches. Both authors read and approved the final manuscript.

Article Information

DOI: $10.9734 / \mathrm{BJESBS} / 2017 / 33510$

Editor(s):

(1) Tsung Hung Lee, Graduate School of Leisure and Exercise Studies, National Yunlin University of Science \& Technology,

Taiwan.

Reviewers:

(1) Prasart Nuangchalerm, Mahasarakham University, Thailand

(2) Nancy Maynes, Nipissing University, Canada.

(3) Aina, Jacob Kola, University of the Western Cape, South Africa.

(4) Amanda Oliveira Rabelo, Universidade Federal Fluminense, Brasil. Complete Peer review History: http://www.sciencedomain.org/review-history/19173

Original Research Article

Received $18^{\text {th }}$ April 2017

Accepted 11 ${ }^{\text {th }}$ May 2017

Published $23^{\text {rd }}$ May 2017

\begin{abstract}
This study aims to investigate whether there are alignments in the characteristics and indicators of the NCATE and Islamic Education Teachers' program. It also examines the consensus of experts in the field of Islamic Education on whether the IET characteristics requested by NCATE standards can be embedded into the Islamic Teacher Preparation Program (ITPP) in Oman. Data were collected from 60 experts, specialists and scholars in a focus group whilst the data were analyzed using descriptive analysis and Delphi techniques in the first and second rounds of analysis. The study found that experts agreed that IET characteristics can be embedded into the ITPP in the College of Education at Sultan Qaboos University. It also reveals that NCATE indicators are aligned with IET indicators. The study has important implications and discussions that can be used for future study.
\end{abstract}

\footnotetext{
*Corresponding author: E-mail: wajeha@squ.edu.om,wajehaalani@gmail.com;
} 
Keywords: Islamic teacher; professional characteristics; standards; teacher preparation.

\section{INTRODUCTION}

People today face a world that is characterized by the rapid and innumerable changes that have taken place in all aspects of life. Society is faced with the tremendous effects of expansions in technology and revolutions of knowledge that require urgent improvement in every sector of life. One of these aspects is the Islamic teacher preparation program which will play a big role in raising a new generation who can master the Islamic knowledge, concepts, principles, and competencies that will help them to become effective citizens. They will also be able to lead development plans and disseminate ideas on improving welfare in their countries.

Recently a lot of work has been done with regards to the Teacher Preparation Program (TPP) in the College of Education at Sultan Qaboos University. This was done as a part of the college plan to be accredited with a certificate from the National Council of Accreditation of Teacher Education (NCATE). The overall aim was to reach the international standard of teacher preparation programs in the College of Education at Sultan Qaboos University. In order to do this, one of the important steps was to analyze the components of each program in the college of Education. One of these programs is the Islamic Education Teacher (IET).

NCATE standards or indicators deal with student knowledge, skills, field practices, assessments, evaluations, social partnership and diversity. IET program standards or indicators talk about personal traits, teaching plans, classroom management, technology skills, social responsibility and citizenship values. The NCATE firmly believes that, when it comes to students' assessment, it should focus first on student knowledge and skills and the assessment should take place both inside and outside class in order to test how students can put theories into practice. According to NCATE, long or short-term assessments and evaluations are required as follow up on students' performance. Such evaluation also helps to identify students' weaknesses and to suggest improvement. Social partnership is also compulsory to identify students' contribution to society and how diversity can be leveraged in teaching and in the classroom.
Looking at the most essential characteristic of effective teachers, much research indicates that teacher personality traits influence how students learn and these traits can result in adverse effects on student outcomes [1,2]. Also teachers should understand the successful completion of classroom management reforms in order to achieve effective classroom management, and maximize the improvement of their students' development [3]. Wilson [4] mentioned the importance of successful classroom management and its effectiveness in maximizing the improvement of the students' development and learning. Ingber [5] referred to the effectiveness of teaching in connecting with science expertise. Beining [6] mentioned the importance of family-teacher partnerships. Saadi [7] highlighted the importance of teachers' understanding of citizenship in Morocco, especially in terms of structure, curricular goals, and implementation. Finally, Stronge [2] confirmed that the characteristics of effective teachers are, in fact, related to student achievement. He mentioned the most essential five domains of qualities that are: teacher as a person, classroom management and organization, planning for instruction, implementing instruction, and monitoring student achievement. Each domain contained many indicators reflected the quality of teachers' professional development.

In Islam, teaching is viewed as a noble job. It requires a wide range of skills and competencies that will help a teacher to practice teaching effectively. A teacher's role in Islam is very important in terms of carrying trust (Amana). The practice of teaching can been seen as a form of worship by helping people to learn and participate effectively in their society. In the Holy Book, the Qur'an, and Prophet's Hadith (Sunnah), many passages clearly mention the important role of scholars and teachers in helping people to acquire knowledge through formal systems in order to maintain the integrity of an Islamic life. With this in mind, Islamic Education scholars assert, in their theory of teaching development, the importance of the total quality management principles that should be embodied in the preparation of the Islamic Education Teacher 'IET' program $[8,9]$.

On the establishment of the College of Education at Sultan Qaboos University in 1989, the Islamic Teacher Preparation Program (ITPP) was 
created to provide the public schools with professional Islamic subject teachers. Since then, many action plans have been taken in order to sustain the development of program outcomes that can meet the market needs of a qualified Islamic teacher. A major revision plan has proceeded in the last ten years. It has triggered a series of strategies to improve ITPP in the College of Education at Sultan Qaboos University. This has been done in order to ensure that the program meets the international criteria and standards of NCATE. This required many actions and development plans to be established to train and professionally equip Islamic school teachers with an understanding of Islamic pedagogy and skills.

The wave of progress began with reforming the criteria of assessment of the teacher preparation program for it to be accredited by national or international organizations. In order to standardize the pedagogy and curriculum of Islamic schools, Memon [10] showed the importance of the principles of education in Islam and how they contribute to raising the standards of Islamic teacher education programs at faculties of education. In the last two decades, many Muslim countries have tried to develop and improve Islamic teacher performance. For example, in Kuwait, Abdulhadi [11] examined the usage of a reflective teaching practice based on the evaluation of teachers in Islamic education. The findings from the study indicated that most teachers in Islamic education in Kuwait were familiar with and practiced reflective teaching. Teachers seemed to have a clear idea of what benefits they might obtain by applying reflective teaching. Despite this, it was observed that there seemed to be some difficulties, such as finishing the curriculum on time. In terms of career development, Supa'ad et al. [12] discuss how personality factors, career planning, and career strategy can provide significant contributions to the success of an Islamic education teacher's career. In Jordan, many efforts have been made in order to create a program that takes entire responsibility for preparing Islamic education teachers. It was found that some areas were in need of improvement, such as reciting the Qur'an with Tajweed, studying different Islamic subjects, taking into account society's needs, and the social system of Islam. It was also found that there was a need for improvement in the methods of teaching, especially in some areas such as appropriate use of technology and educational films, students' skills in problem solving, the organization of cooperative learning activities, and the use of different activities in teaching Islamic education [13].

Another study conducted by $\mathrm{Ag}$ [14] aimed to search for new foundations of philosophy of Islamic Education to revitalize teacher roles and duties in the era of globalization. The result of the study showed that teachers were required to have a strong guideline in performing their duties and roles to accompany the learners in order to have the ability to cope with changing times. In addition to this, Islamic teachers are considered as one of the main pillars of education. Thus, they need to have a strong foundation of educational philosophy in order to have the proper and correct guidance to develop the vision, mission, and educational action to their learners. Almatari's [15] study examined the implementation of high school Islamic education teachers in Saudi Arabia and the usage of innovative approaches in their teaching. The study demonstrated that little attention has been paid to teachers' beliefs about innovation and creativity and how those beliefs may influence teachers' perceptions, as well as their choice of instructional methods and tasks.

In reference to the definition of Islamic Education, Waghid [16] mentioned three conceptions of Islamic education which ought to be considered as existing on a minimalistmaximalist continuum; meaning that the concepts associated with Islamic education do not have a single meaning, but that the meanings are shaped depending on the minimalist and maximalist conditions which constitute them, that is, tarbiyyah (nurturing), ta'lim (learning) and ta`dib (goodness).

\subsection{The Necessities of Islamic Education}

The definition of Islamic Education in the new dictionary of the History of Ideas [17] is a "lifelong pursuit of learning' which is a characteristic ideal of Islamic piety. It underlies the concept of "Islamic" education. While the primary focus of this concept is the nurturing of religious belief in the individual, its scope is broadened to incorporate various secular disciplines, both literary and scientific, as it aimed at developing fully integrated personalities, grounded in the virtues of Islam, within the community. This approach relates to the theory and practice of both primary and higher education. It is evident not only in the Qur'an and the literature of Prophetic Traditions (Hadith), but also in 
countless proverbs, aphorisms, and wisdom sayings, as well as in poetry and prose texts of the Middle Eastern literatures including, in particular, the numerous medieval Arabic works devoted to pedagogical and didactic issues.

Islam is a religion based on Tawhid (oneness of God). The method for reaching the ultimate goal of life is to be virtuous but also to integrate different levels of knowledge. Human beings have been given many different faculties by God. These include, first of all, the mind, then emotions, intuitions, and artistic/aesthetic sensibilities. All of these faculties have to be trained and integrated through the process of education [18].

Nasr [19] mentioned many characteristics of qualified and effective teachers. He began with the ideal situation that no one would be accepted as a teacher unless he or she possessed an ethical character and was sure of his or her vocation. In a deep spiritual sense, this is a God given aptitude. He elaborates, saying that we must find people who have studied well and who are teachers because they want to teach, not because they had no other choice. Teachers should also be trained to be more qualified. There are several important conditions that must be fulfilled in order to accomplish this process. Firstly, the teachers should be primarily Muslim, not only nominally but in their whole conduct and behavior. Secondly, the teachers must be models for the students in several ways: in morality, rightness, truthfulness, and must not be deceitful. Thirdly, the teacher must have a sense of compassion and generosity. In a traditional Islamic civilization this truth was recognized and the teacher was held in much higher esteem compared to the status quo in modern society. A tremendous sense of responsibility is necessary, and, as mentioned above, it is also necessary to always love and to have compassion in addition to knowledge, rectitude, and truthfulness. Fourthly, there has to be a sense of objectivity that comes with truthfulness.

Al-Majali [20] summarized the role of IET in teaching practices across all school levels and stages. He mentioned the teacher duties in raising students' awareness of Islamic religion, history and culture, all of which frame the triangle of learning concepts in IET. They are as following:

- Teaching students the integral and the most required information about Islam;
- Developing students' personalities and identities as Muslim individuals;

- Developing students' understanding about the true perception of Islam in the eyes and minds of other people;

- Establishing students' confidence in their religion, history and heritage;

- Introducing students to actively participate in reviving Muslim unity in all societies; and

- Protecting the Muslim Ummah (nation) from dissolution into another culture.

In order to improve teacher performance in general, and the IET program specifically, teachers should fulfill their important roles with excellence. However, they need training, motivation, as well as regular mental, emotional and spiritual aspirations. Teachers are considered as one of the most essential factors that can lead and improve the quality of education. The educational systems worldwide recognize the importance of a teacher in building an effective model to ensure better access to quality education.

\subsection{Research Purpose}

The aims of this study are to investigate whether the professional characteristics of NCATE standards in the Islamic education teachers' program are embedded in the Islamic Teacher Preparation Program in the College of Education at Sultan Qaboos University and to ascertain whether there is an alignment of NCATE indicators with IET program indicators.

\subsection{Research Question}

The main question of the study is the following:

Is there any alignment, according to the experts' points of view, between the NCATE indicators and the IET characteristics?

\subsection{Conceptual Framework of the Study}

Since 2011, the College of Education (COE) has worked hard in order to develop all the programs offered for accreditation by internationally recognized organizations. After many discussions by the College Board and after considering a plethora of options, it was decided that NCATE would be selected to be the benchmark to accredit all programs. NCATE is considered as the first appraisal institution of national teacher education, which constantly improves the training quality of American 
teachers by being comprehensively appraised [21]. Many committees were formed to begin the journey to meet all the requirements for accreditation. Since then, there have been many consultations and college open days which involved meeting beneficiaries such as parents, Ministry of Education personnel and private administrators, schools and the National Education Board. All college faculties and administrators were committed to work hard in order to meet the requirements.

Therefore, the conceptual framework of this study is shown in Fig. 1 to illustrate how the Islamic Teacher Preparation Program could improve the teaching, knowledge and skills of the Islamic Education teachers.

The conceptual framework in Fig. 1 shows the exchange relationship between the NCATE and ITPP. This has been is established since the College of Education selected the NCATE to be the benchmark to accredit all programs at the college. Based on programs designed to reflect this framework, the Islamic education teacher candidates should become more qualified and efficient when they complete the preparation program.

\section{METHODOLOGY}

In order to achieve the aims of the study, a descriptive approach using a two-round Delphi Technique was used $[22,23]$ to determine the point of view of 60 experts about the major characteristics of Islamic Education (IE) teachers. Each round was followed by a group discussion.

Initially, a list of 95 items representing the major characteristics of IE teachers was derived from the previous literature that mentioned characteristics of the effective teacher $[1,2,3,4,5,6,7]$. A pilot symposium that included a group of people who are interested in IE such as master's students in IE, faculty members from the Department of Curriculum and Instruction, and the Islamic Sciences Department at the College of Education at SQU, and IE supervisors from the Ministry of Education was conducted.

During the symposium, the initial list of 95 items was reviewed and discussed in the focus group discussion sessions to reach agreement on the IE teachers' characteristics. The initial 95 item list was finalized to include a total of 73 items distributed in six domains: personality traits; planning to teach; classroom management; using technology and resources in teaching; social partnership; and disseminating the principals of citizenship. A second Delphi Technique round was conducted to assure and validate the experts' consensus on all 73 items. The fivepoint Likert scale was used to measure the responses of the level of agreement. The words strongly agree, average agree, below average agree, disagree and strongly disagree corresponded to the numbers to $5,4,3,2$, and 1 respectively.

The results of the first round were allocated and provided for the second round. The latter allowed participants to reflect and adjust their opinions. To arrive at an accurate and all-encompassing consensus regarding the questionnaire items, a value of $90 \%$ and over was considered as cut-off point for "strongly agree" in the judgment of consistency and accuracy. It took three months to complete the two Delphi Technique rounds. Based on the results of these two rounds, the process will be aligned between IET indicators in each domain and NCATE standards.

\section{FINDINGS}

\subsection{Demographic Analysis}

Since Delphi technique was used for two rounds with 60 Islamic specialists and scholars, the demographic distribution of those experts is shown in Table 1. It presents the respondents' demographic information. From Table 1, it can be seen that $20 \%$ of respondents were educational supervisors and first year teachers in Islamic Education, $16.7 \%$ were part of the University faculty and school principals whilst $13.3 \%$ were specialists in curriculum design from the Ministry of Education and specialists in the Directorate of Education. It can also be seen from the table that $60 \%$ were male respondents, whilst $40 \%$ were females, with $23.3 \%$ of them holding doctorates.

\subsection{Descriptive Analysis}

Table 2 presents what the Islamic Education specialists and scholars thought about the characteristics of Islamic Teachers.

In order to find the average value of all responses in each domain, the mean average was calculated for each domain in order to find out the percentage of consensus in each domain as shown in Table 3.

The results in Table 3 indicated that the experts tended to agree $100 \%$ in the second round with three characteristics, planning to teach, social 
partnership, and disseminating the principles of citizenship as represented as characteristics of Islamic Education Teachers (IET). In addition to this, $98.61 \%$ to $99 \%$ of the experts or respondents strongly agreed that other characteristics such as personality traits, classroom management and using techniques and resources in teaching, could be embedded in the Islamic Teacher Preparation Program.

\subsection{Alignment between NCATE and IET}

In answering the research question "Is there any alignment according to the experts' point of views between NCATE indicators and IET characteristics? Fig. 2 presents the alignment of NCATE characteristics in the Islamic Education Teacher program with the Islamic Teacher Preparation Program in Oman as created in this research. It demonstrates how the NCATE indicators and IET indicators are related. From the figure below we can see that there is agreement among experts that NCATE indicators of student knowledge and skills can be aligned with IET program personal traits, technological skills and classroom management. Field practices are aligned with planning to teach, social partnership and classroom management. Assessment and evaluation are aligned with planning to teach and technological skills. Social partnership can be aligned with IET social partnership and citizenship values while NCATE Diversity can be aligned with personal traits and citizenship values.

This alignment was proved by first analyzing the content of each NCATE standard and then reviewing 73 Islamic Teacher Preparation programs with the aim of examining if there could be a relationship or alignment between NCATE standards and the ITPP program. The alignment between NCATE and ITPP indicators demonstrates that those indicators can be used as a framework to upgrade the quality of teaching in Islamic Education.

\section{DISCUSSION}

The discussion of this study was derived from two Delphi Technique rounds of discussion with 60 experts and scholars. The discussion explored the extent to which the professional characteristic of the NCATE standards in the Islamic Education Teachers (IET) program could be embedded in the Islamic Teacher Preparation Program (ITPP). It also discussed what the experts and scholars say about the effectiveness of the characteristics of IET in ITPP using first and second rounds of the Delphi technique. The results of this study demonstrate a strong alignment between the NCATE standards or indicators with IET indicators. Thus, it is an indication that NCATE standards go well with the IET characteristics. It can be seen that there is a positive implication of applying or using IET characteristics to improve the Islamic Teacher Preparation Program (ITPP) in Oman. In the meanwhile, in order to be a professional IET, Islamic teachers must meet all those indicators that have been mentioned in Table 2. They should understand the importance of diversity when teaching groups of children, know classroom management techniques, deliver lessons in a accordance with the ethos of their institutions, motivate their students and liaise with those students' parents. This is all in line with Nasr [19] who outlined the ideal characteristics of a qualified Islamic teacher. These included a sense of responsibility, and objectivity, love and passion for teaching, possession of updated knowledge, rectitude and truthfulness.

Since the experts and specialists agree that the NCATE standards align or compliment IET program indicators, the IET program or indicators can be used to improve the Islamic Teacher Preparation Program (ITPP). These standards can be utilized to re-skill teachers in their professions and increase their performance. With a symbiotic relationship between the IET program indicators and NCATE standards, the IET program can be seen as a benchmark or framework in preparing teachers in Oman to upgrade their skills in the field of teaching, as well as to enhance their professional development.

With the personal traits aligning with students' knowledge and skills in this study, the alignment supports Supa'ad et al. [12] argument that personality plays a big role in the success of Islamic education teachers' careers. Moreover, as technological skills are deemed, by this study, to be aligned with student knowledge and skills, these findings support the findings of Almatari [15] that show how little attention is paid to teachers' beliefs and perceptions toward using technology for innovation. It also supports Almatari's [15] findings on how teacher belief and perceptions towards technology and innovation might affect teachers in choosing the right methods for instruction. 
The study findings that report the alignment of technology for assessment, evaluation and knowledge skills also support Alkhawalden's [13] statement on the need to improve methods of teaching, students' skills and problem solving using technology. Once again, the alignment found between the NCATE indicators with IET indicators for ITTP improvement is in line with Memon's [10] statement and argument for standardizing the pedagogy and curriculum of Islamic schools to improve education in Islam and raise the standards of Islamic teacher education programs at faculties of education in Oman.

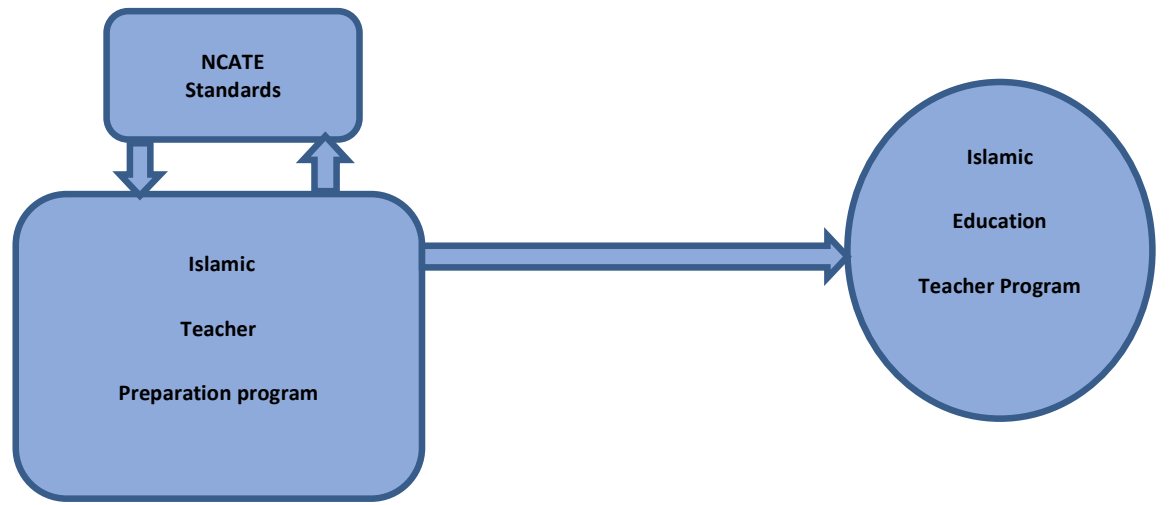

Fig. 1. The conceptual framework

Table 1. Respondents' demographic information

\begin{tabular}{|c|c|c|c|c|c|c|}
\hline \multirow[t]{2}{*}{ Occupation } & \multicolumn{2}{|c|}{ Gender } & \multicolumn{3}{|c|}{ Qualification } & \multirow[t]{2}{*}{ Total } \\
\hline & Male & Female & PhD & Master & Bachelor & \\
\hline University faculty & 6 & 4 & 10 & & & 10 \\
\hline $\begin{array}{l}\text { Specialist in curriculum design from } \\
\text { Ministry of Education }\end{array}$ & 5 & 3 & & 8 & & 8 \\
\hline $\begin{array}{l}\text { Specialist in the Directorate of } \\
\text { Education }\end{array}$ & 8 & & 2 & 5 & & 8 \\
\hline School principals & 5 & 5 & & 8 & 2 & 10 \\
\hline Educational supervisors & 6 & 6 & 2 & 8 & 2 & 12 \\
\hline $\begin{array}{l}\text { First year teachers in Islamic } \\
\text { education }\end{array}$ & 6 & 6 & & 8 & 4 & 12 \\
\hline Total & 36 & 24 & 14 & 38 & 8 & 60 \\
\hline
\end{tabular}

Table 2. Specialists agree about the effectiveness of Islamic Teacher indicators in the first and second rounds of the Delphi technique

\begin{tabular}{|c|c|c|c|c|c|}
\hline \multicolumn{2}{|c|}{ Indicator domains } & \multicolumn{2}{|c|}{$\begin{array}{l}\text { First round } \\
\text { agreement }\end{array}$} & \multicolumn{2}{|c|}{$\begin{array}{l}\text { Second round } \\
\text { agreement }\end{array}$} \\
\hline Stat & nent & $\mathbf{n}$ & $\%$ & $\mathbf{n}$ & $\%$ \\
\hline \multicolumn{6}{|c|}{ 1-Personality traits indicator } \\
\hline 1. & $\begin{array}{l}\text { Deals with his/her colleagues and students using good } \\
\text { manners }\end{array}$ & 58 & $96.6 \%$ & 60 & $100 \%$ \\
\hline 2. & Committed to appropriate body manners & 60 & $100 \%$ & 60 & $100 \%$ \\
\hline 3. & $\begin{array}{l}\text { Characterized by fidelity in the performance of his/her } \\
\text { duties }\end{array}$ & 60 & $100 \%$ & 60 & $100 \%$ \\
\hline 4. & Concerned for justice amongst his/her students & 56 & $93.3 \%$ & 58 & $100 \%$ \\
\hline 5. & Characterized by flexibility in dealing with others & 53 & $88.3 \%$ & 56 & $93.3 \%$ \\
\hline 6. & $\begin{array}{l}\text { Working to set a good example in behavior inside and } \\
\text { outside the school }\end{array}$ & 60 & $100 \%$ & 60 & $100 \%$ \\
\hline 7. & $\begin{array}{l}\text { Characterized by activity and vitality when performing } \\
\text { his/her duties }\end{array}$ & 57 & $95 \%$ & 59 & $98.3 \%$ \\
\hline
\end{tabular}




\begin{tabular}{|c|c|c|c|c|c|}
\hline \multicolumn{2}{|c|}{ Indicator domains } & \multicolumn{2}{|c|}{$\begin{array}{l}\text { First round } \\
\text { agreement }\end{array}$} & \multicolumn{2}{|c|}{$\begin{array}{l}\text { Second round } \\
\text { agreement }\end{array}$} \\
\hline \multicolumn{2}{|c|}{ Statement } & $\mathbf{n}$ & $\%$ & $\mathbf{n}$ & $\%$ \\
\hline 8. & $\begin{array}{l}\text { Characterized by accepting the opinions of others, and } \\
\text { lack of bias in his/her views }\end{array}$ & 59 & $98.3 \%$ & 60 & $100 \%$ \\
\hline 9. & Showing attributes such as dignity and prestige & 60 & $100 \%$ & 60 & $100 \%$ \\
\hline 10. & Characterized by patience and restraint & 60 & $100 \%$ & 60 & $100 \%$ \\
\hline 11. & $\begin{array}{l}\text { Characterized by the ability to persuade using proof and } \\
\text { evidence }\end{array}$ & 58 & $96.6 \%$ & 59 & $98.3 \%$ \\
\hline 12. & Is charismatic and powerful & 56 & $93.3 \%$ & 58 & $96.6 \%$ \\
\hline \multicolumn{6}{|c|}{ 2-Planning to teach indicators } \\
\hline 13. & $\begin{array}{l}\text { Prepares a comprehensive plan for quarterly programs } \\
\text { for Islamic Education }\end{array}$ & 59 & $98.3 \%$ & 60 & $100 \%$ \\
\hline 14. & Plans to offer lesson elements sequentially & 60 & $100 \%$ & 60 & $100 \%$ \\
\hline 15. & $\begin{array}{l}\text { Formulates lesson objectives in an observable and } \\
\text { measurable way }\end{array}$ & 60 & $100 \%$ & 60 & $100 \%$ \\
\hline 16. & $\begin{array}{l}\text { Formulates targets that take into account the diversity } \\
\text { of learners' abilities }\end{array}$ & 60 & $100 \%$ & 60 & $100 \%$ \\
\hline 17. & $\begin{array}{l}\text { Plans activities associated with the classroom } \\
\text { curriculum of Islamic education }\end{array}$ & 60 & $100 \%$ & 60 & $100 \%$ \\
\hline 18. & Distributes lesson targets allocated to share time & 60 & $100 \%$ & 60 & $100 \%$ \\
\hline 19. & $\begin{array}{l}\text { Plans for extra-curricular activities, including enriching } \\
\text { the curriculum of Islamic education }\end{array}$ & 60 & $100 \%$ & 60 & $100 \%$ \\
\hline 20. & $\begin{array}{l}\text { Using calendar design methods related to the } \\
\text { objectives of the lesson }\end{array}$ & 60 & $100 \%$ & 60 & $100 \%$ \\
\hline 21. & $\begin{array}{l}\text { Designs tools and educational technologies appropriate } \\
\text { to the theme of the lesson }\end{array}$ & 57 & $95 \%$ & 58 & $96.6 \%$ \\
\hline 22. & $\begin{array}{l}\text { Plans lessons to develop critical thinking skills amongst } \\
\text { students }\end{array}$ & 60 & $100 \%$ & 60 & $100 \%$ \\
\hline \multicolumn{6}{|c|}{ 3-Classroom management indicators } \\
\hline 23. & Provides a descriptive environment based on tolerance & 56 & $93.3 \%$ & 55 & $91.6 \%$ \\
\hline 24. & $\begin{array}{l}\text { Objectively deals with behavioral problems that occur } \\
\text { inside the classroom }\end{array}$ & 60 & $100 \%$ & 60 & $100 \%$ \\
\hline 25. & Manages the time quota Carefully & 60 & $100 \%$ & 60 & $100 \%$ \\
\hline 26. & $\begin{array}{l}\text { Uses effective strategies and methods suitable for } \\
\text { classroom management }\end{array}$ & 60 & $100 \%$ & 60 & $100 \%$ \\
\hline 27. & $\begin{array}{l}\text { Improves the management of diverse curricular } \\
\text { activities }\end{array}$ & 60 & $100 \%$ & 60 & $100 \%$ \\
\hline 28. & $\begin{array}{l}\text { Improves emergency classroom situations / crisis } \\
\text { management }\end{array}$ & 60 & $100 \%$ & 60 & $100 \%$ \\
\hline 29. & $\begin{array}{l}\text { Announces regulations approved in classroom } \\
\text { management (entry, exit, delivery obligations, } \\
\text { authorization, instructions and directives ...etc.) }\end{array}$ & 60 & $100 \%$ & 60 & $100 \%$ \\
\hline 30. & Improves work management teams among students & 57 & $95 \%$ & 59 & $98.3 \%$ \\
\hline 31. & $\begin{array}{l}\text { Creates an organizational culture in the classroom } \\
\text { based on student participation }\end{array}$ & 59 & $98.3 \%$ & 60 & $100 \%$ \\
\hline 32. & $\begin{array}{l}\text { Encourages students participate in the responsibility } \\
\text { of making decisions related to their education }\end{array}$ & 60 & $100 \%$ & 60 & $100 \%$ \\
\hline \multicolumn{6}{|c|}{ 4-Using techniques and resources in teaching indicators } \\
\hline 33. & Uses a computer to organize student records & 60 & $100 \%$ & 60 & $100 \%$ \\
\hline 34. & $\begin{array}{l}\text { Uses a PowerPoint program in the presentation of } \\
\text { some but not all, Islamic education lessons }\end{array}$ & 60 & $100 \%$ & 60 & $100 \%$ \\
\hline 35. & Uses simulation software in teaching & 60 & $100 \%$ & 60 & $100 \%$ \\
\hline 36. & $\begin{array}{l}\text { Benefits from educational portal services in the } \\
\text { performance of his/her duties }\end{array}$ & 60 & $100 \%$ & 60 & $100 \%$ \\
\hline
\end{tabular}




\begin{tabular}{|c|c|c|c|c|c|}
\hline \multicolumn{2}{|c|}{ Indicator domains } & \multicolumn{2}{|c|}{$\begin{array}{l}\text { First round } \\
\text { agreement }\end{array}$} & \multicolumn{2}{|c|}{$\begin{array}{l}\text { Second round } \\
\text { agreement }\end{array}$} \\
\hline \multicolumn{2}{|c|}{ Statement } & $n$ & $\%$ & $n$ & $\%$ \\
\hline 37. & $\begin{array}{l}\text { Employs computerized educational programs } \\
\text { appropriate to the capacity of students in their } \\
\text { recitation development }\end{array}$ & 60 & $100 \%$ & 50 & $100 \%$ \\
\hline 38. & $\begin{array}{l}\text { Looks at websites for activities to help in the } \\
\text { development of the talents and creations of students }\end{array}$ & 58 & $96.6 \%$ & 60 & $100 \%$ \\
\hline 39. & $\begin{array}{l}\text { Is following developments in electronic networking } \\
\text { sites relevant to the content of the curriculum of } \\
\text { Islamic education }\end{array}$ & 60 & $100 \%$ & 60 & $100 \%$ \\
\hline 40. & $\begin{array}{l}\text { Uses computer programs in the preparation of daily } \\
\text { classroom activities and decisions of Islamic } \\
\text { Education Plans }\end{array}$ & 60 & $100 \%$ & 60 & $100 \%$ \\
\hline 41. & $\begin{array}{l}\text { Employs technology in the process of evaluating the } \\
\text { performance of students }\end{array}$ & 53 & $88.3 \%$ & 55 & $91.6 \%$ \\
\hline 42. & $\begin{array}{l}\text { Uses designed data to store information and } \\
\text { references in the field of Islamic education rules }\end{array}$ & 58 & $96.6 \%$ & 59 & $98.3 \%$ \\
\hline 43. & $\begin{array}{l}\text { Uses designed methods of electronic learning (video } \\
\text { tutorial) }\end{array}$ & 57 & $95 \%$ & 59 & $98.3 \%$ \\
\hline 44. & $\begin{array}{l}\text { Develops students' ability to use computerized } \\
\text { educational programs in the field of graduate } \\
\text { conversations }\end{array}$ & 60 & $100 \%$ & 60 & $100 \%$ \\
\hline 45. & $\begin{array}{l}\text { Employs computerized programs in developing } \\
\text { students' abilities in calculating the division of heirloom } \\
\text { value }\end{array}$ & 60 & $100 \%$ & 60 & $100 \%$ \\
\hline 46. & $\begin{array}{l}\text { Has designed an electronic forum that specializes in } \\
\text { education }\end{array}$ & 60 & $100 \%$ & 60 & $100 \%$ \\
\hline \multicolumn{6}{|c|}{ 5-Social partnership indicators } \\
\hline 47. & $\begin{array}{l}\text { Collaborates with the students' parents to improve their } \\
\text { children's learning }\end{array}$ & 60 & $100 \%$ & 60 & $100 \%$ \\
\hline 48. & $\begin{array}{l}\text { Works on linking the contents of the curriculum with } \\
\text { the local community }\end{array}$ & 60 & $100 \%$ & 60 & $100 \%$ \\
\hline 49. & $\begin{array}{l}\text { Works to solve the problems of students by involving } \\
\text { parents }\end{array}$ & 60 & $100 \%$ & 60 & $100 \%$ \\
\hline 50. & $\begin{array}{l}\text { Directs students to participate in volunteer activities in } \\
\text { the community }\end{array}$ & 59 & $98.3 \%$ & 60 & $100 \%$ \\
\hline 51. & $\begin{array}{l}\text { Works to build a close relationship with the relevant } \\
\text { education partners in Islamic society institutions such } \\
\text { as mosques, clubs, and the family in court }\end{array}$ & 60 & $100 \%$ & 60 & $100 \%$ \\
\hline 52. & $\begin{array}{l}\text { Collaborates with educational institutions of society } \\
\text { (mosques, clubs, and in court the family) in the } \\
\text { dissemination of science }\end{array}$ & 58 & $96.6 \%$ & 60 & $100 \%$ \\
\hline 53. & $\begin{array}{l}\text { Collaborates with civil society organizations in raising } \\
\text { awareness in the field of Islamic education }\end{array}$ & 60 & $100 \%$ & 60 & $100 \%$ \\
\hline & $\begin{array}{l}\text { Offers public lectures to educate members of the } \\
\text { community about various religious events }\end{array}$ & 60 & $100 \%$ & 60 & $100 \%$ \\
\hline 55. & $\begin{array}{l}\text { Evaluates a community partnership in the development } \\
\text { of Islamic education programs }\end{array}$ & 60 & $100 \%$ & 60 & $100 \%$ \\
\hline & $\begin{array}{l}\text { Employs electronic social networking sites to } \\
\text { communicate with the parents of students }\end{array}$ & 60 & $100 \%$ & 60 & $100 \%$ \\
\hline \multicolumn{6}{|c|}{ 6- Disseminating the principles of citizenship indicators } \\
\hline & $\begin{array}{l}\text { Develops loyalty to the homeland and defends the } \\
\text { sanctities of the students }\end{array}$ & 60 & $100 \%$ & 60 & $100 \%$ \\
\hline & $\begin{array}{l}\text { Fosters students' pride of their Islamic identity and } \\
\text { traditions (customs and traditions of authentic } \\
\text { Omanis) }\end{array}$ & 60 & $100 \%$ & 60 & $100 \%$ \\
\hline
\end{tabular}




\begin{tabular}{|c|c|c|c|c|c|}
\hline \multicolumn{2}{|c|}{ Indicator domains } & \multicolumn{2}{|c|}{$\begin{array}{l}\text { First round } \\
\text { agreement }\end{array}$} & \multicolumn{2}{|c|}{$\begin{array}{l}\text { Second round } \\
\text { agreement }\end{array}$} \\
\hline \multicolumn{2}{|c|}{ Statement } & $\mathbf{n}$ & $\%$ & $\mathbf{n}$ & $\%$ \\
\hline 59. & Directs students to maintain public property & 60 & $100 \%$ & 60 & $100 \%$ \\
\hline 60. & $\begin{array}{l}\text { Promotes loyalty to the leader of the country and work } \\
\text { directives }\end{array}$ & 60 & $100 \%$ & 60 & $100 \%$ \\
\hline 61. & $\begin{array}{l}\text { Requests that Islamic teachings be taken into account } \\
\text { in dealings with others }\end{array}$ & 60 & $100 \%$ & 60 & $100 \%$ \\
\hline 62. & $\begin{array}{l}\text { Urges students to have devotion to God in word and } \\
\text { deed }\end{array}$ & 60 & $100 \%$ & 60 & $100 \%$ \\
\hline 63. & $\begin{array}{l}\text { Enhances students' adherence to national identity, } \\
\text { patriotism and sense of belonging }\end{array}$ & 60 & $100 \%$ & 60 & $100 \%$ \\
\hline 64. & $\begin{array}{l}\text { Enhances the inherent values of the community and } \\
\text { its habits amongst students }\end{array}$ & 60 & $100 \%$ & 60 & $100 \%$ \\
\hline 65. & $\begin{array}{l}\text { Directs students to renounce violence and fight terror } \\
\text { and deviant thoughts }\end{array}$ & 60 & $100 \%$ & 60 & $100 \%$ \\
\hline 66. & $\begin{array}{l}\text { Deals with the students on the concept of citizenship } \\
\text { based on justice and equality }\end{array}$ & 60 & $100 \%$ & 60 & $100 \%$ \\
\hline 67. & $\begin{array}{l}\text { Enhances students' understanding of the culture and } \\
\text { respect for others }\end{array}$ & 60 & $100 \%$ & 60 & $100 \%$ \\
\hline 68. & $\begin{array}{l}\text { Encourages students to participate in volunteer work in } \\
\text { all its forms }\end{array}$ & 60 & $100 \%$ & 60 & $100 \%$ \\
\hline 69. & $\begin{array}{l}\text { Gives students the freedom to express themselves and } \\
\text { participate in constructive dialogue }\end{array}$ & 59 & $98.3 \%$ & 60 & $100 \%$ \\
\hline 70. & Promotes teamwork amongst students & 59 & $98.3 \%$ & 60 & $100 \%$ \\
\hline 71. & $\begin{array}{l}\text { Promotes a culture of openness to others whilst also } \\
\text { upholding Islamic values }\end{array}$ & 60 & $100 \%$ & 60 & $100 \%$ \\
\hline 72. & $\begin{array}{l}\text { Explains to students the concept of diversity and } \\
\text { acceptance of others }\end{array}$ & 60 & $100 \%$ & 60 & $100 \%$ \\
\hline 73. & $\begin{array}{l}\text { Bases discussions between the teacher and the } \\
\text { students on the acceptance of the principle of exchange }\end{array}$ & 60 & $100 \%$ & 60 & $100 \%$ \\
\hline
\end{tabular}

Table 3. Expert's consensus with the embedment of NCATE characteristics of IET in ITPP in the first and second rounds of the Delphi technique

\begin{tabular}{llllll}
\hline No & Domains & \multicolumn{2}{c}{$\begin{array}{c}\text { First round } \\
\text { agreement }\end{array}$} & \multicolumn{2}{c}{$\begin{array}{c}\text { Second round } \\
\text { agreement }\end{array}$} \\
\hline & & Average & $\%$ & Average & $\%$ \\
\hline 1. & Personality traits & 58.08 & $96.81 \%$ & 59.17 & $98.61 \%$ \\
2. & Planning to teach & 59.6 & $99 \%$ & 59.8 & $100 \%$ \\
3. & Classroom management & 59.2 & $99 \%$ & 59.4 & $99 \%$ \\
4. & Using techniques and resources in & 59 & $98 \%$ & 59.5 & $99 \%$ \\
& teaching & & & & \\
5. & Social partnership & 59.7 & $100 \%$ & 60 & $100 \%$ \\
6. & Disseminating the principles of citizenship & 59.8 & $99 \%$ & 60 & $100 \%$ \\
\hline
\end{tabular}

NCATE Indicators

IET Indicators

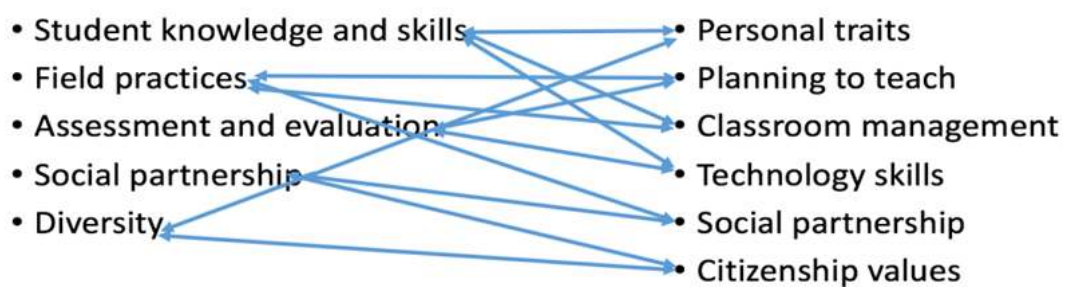

Fig. 2. Shows the alignment of NCATE and IET indicators 


\section{CONCLUSION}

The main purpose of this study was to determine the characteristics of the ideal Islamic teacher, based on a consensus of viewpoints from experts in the field of Islamic education. The results of the study show that there are 73 indicators distributed across six domains. These indicators represented teacher practices and teaching implementations that are mentioned in the NCATE [24] standards for teacher preparation programs. They are also part of the College of Education conceptual framework, although that was created from the NCATE standards.

The main conclusion of this study shows that there are six domains which frame teacher preparation for Islamic education. These are as follow:

\subsection{Indicators of Personality Traits}

These focus on the teachers' manners and on qualities such as justice, patience, fidelity, loyalty, dignity, flexibility and performance as a role model.

\subsection{Indicators of Teaching Preparation}

These focus on teaching effectiveness, including design of lesson plans formulation of learning objectives; design of classroom activities (that are appropriate to the students' diversity and interests); use of appropriate educational tools and technology.

\subsection{Indicators of Classroom Management}

These focus on teachers' time management in class; the setting of classroom regulations; the encouragement of student participation; the ability to manage crises; and the creation of a safe and secure classroom environment.

\subsection{Indicators of Teaching Techniques and Resources}

These focus on teachers' ability to convey subject knowledge; the design of learning networks sites; the employment of technology in evaluating student performance; and the use of video to enhance teaching.

\subsection{Indicators of Social Partnerships}

These focus on the teachers' ability to build a collaborative relationship with the local community, in civil organizations, Islamic institutions, and social networks. Such partnerships should also involve students' parents and extended families.

\subsection{Indicators Disseminating of the Principles of Citizenship}

These focus at the teachers' ability to develop loyalty toward the nation; fostering pride in their Islamic identity and heritage, and enhancing their understanding of the Islamic culture of tolerance, and acceptance of others. The teacher should also develop positive student attitudes to voluntary work.

\section{IMPLICATION}

This study resulted in some important implications. One of these implications is that since the research has found strong alignment between the NCATE indicators or characteristics with IET program indicators and characteristics, this shows a positive implementation and the benefits of using IET program indicators to improve Islamic Teacher Preparation Programs in Oman. In the process, the NCATE could be seen or perceived as a framework or benchmark for ITPP because NCATE indicators are an international educational standard used to improve teachers' skills and teaching. If the NCATE standards can be fully utilized or applied in ITPP, they could provide input to ITPP while producing favorable outputs for the educational systems in Oman.

In the meantime, IET practices in schools are respected and ranked highly in Islam as they combine religion with natural sciences. With the experts and scholars in the field of Islamic studies and teacher education agreeing that NCATE indicators are well aligned with IET program indicators, it is good news to see both standards match up well. With this result, the Omani MOE should take the opportunity to use the IET program to improve the curriculum, syllabus and train Islamic teachers on how to improve their teaching as well as upgrade their skills. The model in Fig. 2 demonstrates how the NCATE can be aligned with the IET program. In this alignment, the IET program can be used to measure the effectiveness of Islamic Education teachers' practices in public schools in Oman. No matter where IET program falls, i.e., whether it reflects physical or spiritual components, it can still be embraced and embedded into ITTP to 
raise the standard of teaching and teacher performance in Oman.

This paper contributes to ongoing research and work on teacher improvement in the world and specifically in Oman. In Oman, teacher training and development has been the Omani MOE's top priority. Since the Omani Renaissance, Oman has placed focus and emphasis on training teachers. Any research on teacher training and development is highly welcomed in Oman by the Ministry of Education. As this research focuses on training Islamic teachers through Islamic Education Teachers Program Indicators that have been positively aligned with NCATE standards, it means this research is both apposite and unique in the process of developing Islamic teachers' knowledge and skills, as well as in preparing advanced programs using international standards. It is also unique as the programs provided around the world are often for non-Islamic teachers. This paper, however, has invested time and effort to examine how NCATE, an internationally recognized and highly educational program for teachers fits into Islamic programs. It has been discovered that the Islamic Education Teachers (IET) program that has been accredited by NCATE can be used to improve and upgrade the Omani Islamic Teacher Preparation Program (ITTP). This can be considered an important contribution to the body of knowledge related to Islamic teachers' training and development in Oman and in other Arab states.

\section{COMPETING INTERESTS}

Authors have declared that no competing interests exist.

\section{REFERENCES}

1. Burch SQ. An examination of teacher perceptions of professional development through the framework of individual personality traits; 2016. (Order No. 10124963). From ProQuest Dissertations \& Theses Global. (1809101093).

Available:https://ezproxysrv.squ.edu.om:21 23/docview/1809101093?accountid $=27575$

2. Stronge JH. Qualities of effective teachers. 2nd ed. Alexandria: VA. USA; 2007.

3. Wang R. Management of the primary qualities of classroom teaching; 2011. (Order No. 10548571). From ProQuest Dissertations \& Theses Global. (1870405693).
Available:https://ezproxysrv.squ.edu.om:21 23/docview/1870405693?accountid=27575

4. Wilson KS. Teacher perceptions of classroom management practices in public elementary schools; 2006. (Order No. 3257688). From ProQuest Dissertations \& Theses Global. (304973770).

Available:https://ezproxysrv.squ.edu.om:21 23/docview/304973770?accountid=27575

5. Ingber JD. A comparison of teachers' pedagogical content knowledge while planning in and out of their science expertise; 2009. (Order No. 3373761). From ProQuest Central; ProQuest Dissertations \& Theses Global. (304864731).

Available:https://ezproxysrv.squ.edu.om:21 23/docview/304864731?accountid=27575

6. Beining $\mathrm{KH}$. Family-teacher partnerships: An early childhood contract for success. Childhood Education. 2011;87(5):361-363. Available:https://ezproxysrv.squ.edu.om:21 23/docview/875892822?accountid $=27575$

7. Saadi T. How do Moroccan teachers conceptualize citizenship? 2015. (Order No. 3720024). From ProQuest Dissertations \& Theses Global. (1718547422).

Available:https://ezproxysrv.squ.edu.om:21 23/docview/1718547422? accountid $=27575$

8. Rahman M. A holistic and institutional analysis of Islamic education. The American Journal of Islamic Social Sciences. 1994;11(4):591-531.

9. Shah S. Islamic education and the UK Muslims: Options and expectations in a context of multi-locationality. Studies in Philosophy and Education. 2014;33(3): 233-249.

DOI:http://dx.doi.org/10.1007/s11217-0139391-2

10. Memon N. What Islamic school teachers want: Towards developing an Islamic teacher education programme. British Journal of Religious Education. 2011; 33(3):285-298.

Available:http://search.proquest.com/docvi ew/889924868?accountid=27575

11. Abdulhadi MM. An exploration and examination of reflective teaching practice among teachers of Islamic education in Kuwaiti middle schools; 2001. (Order No. 3022429). From ProQuest Dissertations \& Theses Global. (304713527). 
Available:http://search.proquest.com/docvi ew/304713527?accountid=27575

12. Supa'ad M, Wahat NW, Fakhruddin FM, Suandi T. Factors contributing to the subjective career success among Islamic Educators in Primary Schools. International Journal of Education \& Literacy Studies. 2013;1(1):55.

DOI: $10.7575 / a i a c . i j e l s . v .1 n .1 p .55$

13. Alkhawaldeh NA. Assessment of the program for preparing Islamic education teachers in Jordanian public universities. 1996. (Order No. 9623618). From ProQuest Dissertations \& Theses Global. (304276300).

Available:http://search.proquest.com/docvi ew/304276300?accountid $=27575$

14. Ag HA. A study for searching new foundation of philosophy of Islamic education to revitalizing the teacher roles and duties in globalization era. International Journal of Social Science and Humanity. 2014; 4(5):391-396.

DOI:http://dx.doi.org/10.7763/IJSSH.2014. V4.385

15. Almatari BM. To what extent do high school Islamic education teachers in Saudi Arabia implement innovative approaches in their teaching? Do teacher gender, academic qualifications, and teaching experiences matter? 2012. (Order No. 3541645). From ProQuest Dissertations \& Theses Global. (1115148918).

Available:http://search.proquest.com/docvi ew/1115148918?accountid $=27575$

16. Waghid $\mathrm{Y}$. Islamic education and cosmopolitanism: A philosophical interlude. Studies in Philosophy and Education. 2014; 33(3):329-342.

DOI:http://dx.doi.org/10.1007/s11217-0139390-3

17. New Dictionary of the History of Ideas (2005). Islamic Education definition. The Gale Group, Inc.
(Retrieved 29-1-2017)

Available:http://www.encyclopedia.com/hist ory/dictionaries-thesauruses-pictures-andpress-releases/islamic-education

18. Abdullah M, Azmi Jasmi K. Characteristics of excellent Islamic education lectures in teaching education institute of Malaysia. International Journal of Psychology and Counseling. 2014;6(11):145-151.

19. Nasr SH. Islamic pedagogy: An interview. Islam \& Science. 2012;10(1):724.

Available:http://search.proquest.com/docvi ew/1032530132?accountid $=27575$

20. Al-Majali M. Islamic culture and thought. Reviewed by: Abdul-Fattah A. Hannud. Faculty of Islamic Studies. Jordan: University of Jordan Publisher; 2008.

21. Johnson DD, Johnson B, Farenga SJ, Ness D. Trivializing teacher education; 2005. The accreditation squeeze Rowman \& Littlefield Publishers, 15200 NBN Way, P.O. Box 191, Blue Ridge Summit, PA 17214-0191.

Available:https://ezproxysrv.squ.edu.om:21 23/docview/62086595?accountid=27575

22. Cohen L, Manion L, Morrison K. Research methodology in education. $6^{\text {th }}$ ed. USA: Routledge Publisher; 2007.

23. Robson C. Real world research a resource for social scientists and practitioner researchers. $2^{\text {nd }}$ ed. USA: Blackwell Publishing; 2002.

24. NCATE. Professional standards Accreditation of Teacher Preparation Institutions. National council for accreditation of teacher education The Standard of Excellence in Teacher Preparation. Massachusetts Avenue: NW; 2010.

Available:http://www.ncate.org/documents/ standards/NCATE\%20Standards\%202008 .pdf

(c) 2017 Al-Ani and Al-Zadgali; This is an Open Access article distributed under the terms of the Creative Commons Attribution License (http://creativecommons.org/licenses/by/4.0), which permits unrestricted use, distribution, and reproduction in any medium, provided the original work is properly cited. http://sciencedomain.org/review-history/19173 